\title{
Outcome of Cochlear Implantation in Post-Meningitis Deaf Children
}

\author{
Mahdiyeh Hasanalifard ${ }^{1}$, Mohammad Ajalloueyan ${ }^{1}$, Susan Amirsalari ${ }^{1}$, Amin Saburi ${ }^{1,}$ \\ ${ }^{1}$ New Hearing Technologies Research Center, Baqiyatallah University of Medical Sciences, Tehran, IR Iran \\ * Corresponding author: Susan Amirsalari, New Hearing Technologies Research Center, Baqiyatallah University of Medical Sciences, Tehran, IR Iran. Tel.: \\ +98-2188600067, E-mail: susanamirsalari@yahoo.com
}

Keywords: ENT; Pediatrics; Pediatrics Surgery

\section{Dear Editor,}

Cochlear implantation (CI) is an effective procedure for treatment of children with severe to profound Sensorineural hearing loss (SNHL). In spite of suitable outcome in many patients, choosing the candidates should be regarding to the child age and etiology (congenital or acquired SNHL) (1-4). Bacterial meningitis (BM) is one of the most common etiologies of acquired SNHL which estimated approximately 60 - $90 \%$ of all cases of secondary SNHL at children (5). Due to concomitant neurological sequelae such as seizure, visual impairment and hydrocephalus, the successful outcome of $\mathrm{CI}$ in these cases remained doubtful. We introduce a case series about outcome of cochlear implantation at children with SNHL due to BM as the preliminary report from Iran. Two hundred eighty-four children with hearing loss presenting to the cochlear implantation center of the Baqiyatallah Hospital between 2008 and 2010 were evaluated and finally, eight children with Post Meningitis deafness (PMD) were enrolled. Profound SNHL was confirmed based on the average of pre-implantation unaided pure-tone thresholds over $90 \mathrm{~dB}$. There were complementary investigations for overruling other cause of SNHL. The Nucleus 22 channel device and a speech processors device was used, routinely although other option has been considered in special subjects. Each cases assessed by Nerve Response Telemetry (NRT) intra-operatively and 45 days after surgery. Speech Intelligibility Rating (SIR) and Categories of Auditory Perception scale (CAP) tests was conducted in the best-aided situation both before and after implantation.6 All cases were assessed at three, six, 12, and 24 months after CI. This investigation was approved by the ethical review board. The mean age of children at the meningitis diagnosis was $15.75 \pm 6.77$ (Mean \pm SD) months and the mean age at cochlear implantation was $31.12 \pm 1.27$ months. Two patients was male (patients number $1 \& 4$ ). The microorganism cultured from the CSF was identified in $3(37.5 \%)$ patients. In three patients (No. 1, 3\&4) the causative microorganism was Streptococcus Pneumoniae (Pneumococcus) and in other subjects causative microorganisms were unknown. Electrode insertion in 6 out of eight patients was complete but two children required cochlear drill-out and in one child short electrodes was used. There was no serious complication after operation during 6 months follow up. The mean of NRT at the baseline, 3 and 6 months later was $69.37 \pm 96.78,187.37 \pm 19.24$ and 184.62 \pm 17.32 , respectively ( Table 1 ). We used SPSS version 16 and repeated measured ANOVA test to compare the CAP and SIR findings. By using this test we were able to compare the CAP and SIR score between more than two stages ( 0 , 3 and 6 month after implantation). Three months after CI, the mean score of CAP test developed from $0.62 \pm 0.74$ at the baseline to $3.00 \pm 1.41$ and also increased to $3.75 \pm 1.16$ at the 6-months after $\mathrm{CI}(\mathrm{P}<0.001)$. Also, SIR scored a mean of $1.25 \pm 0.46$ at the baseline improved to $1.37 \pm 0.74$ at 3 months after implantation $(\mathrm{P}=0.351)$ and a mean of 2.25 \pm 0.88 at 6 months later $(\mathrm{P}<0.001)$ ( Table 2 ). Previously, the $\mathrm{CI}$ success and efficacy in children with additional disability such as PMD compared to children with pure SNHL were debatable $(6,7)$. This supposition was because of having concomitant neurological squeal. The electrode may be inserted incompletely due to ossified cochlea (8), although, results of several previous studied were equivocal. Howard et al recommended that neurologic squeal of

Article type: Letter; Received: 01 Nov 2011, Revised: 10 Mar 2012, Accepted: 06 Apr 2012; DOI: 10.5812/ircmj.3394

-Please cite this paper as:

Hasanalifard M, Ajalloueyan M, Amirsalari S, Saburi A. Outcome of Cochlear Implantation in Post-Meningitis Deaf Children. Iran Red Cres Med J. 2013:15(1).15-7. DOI: 10.5812/ircmj.3394

Copyright (C) 2013, Iranian Red Crescent Medical Journal; Published by Kowsar Corp.

This is an Open Access article distributed under the terms of the Creative Commons Attribution License (http://creativecommons.org/licenses/by/3.0), which permits unrestricted use, distribution, and reproduction in any medium, provided the original work is properly cited. 
BM annoy the improvement of speech perception after $\mathrm{CI}$ in patients with PMD (9) El-Kashlan et al. showed children with cochlear ossification due to BM have significant lower speech perception improvement than a matched control children with congenital SNHL at both the 6 and 24-month follow-up after CI but with extended follow-up, some children with ossification had speech perception partially (10). Eshragi et al. revealed children with PMD and those with cochlear ossification who undergo CI may require frequent programming adjustments to obtain the optimal performance because levels of stimulation increase over the time (11). Partial insertion is more suitable and comfortable than complete insertion in ossified cochlea or labyrinth for surgeons (12). Age and causative microorganism are important factors to determinate the outcome in children with post meningitis deafness (13). Also, the role of time between PMD and implantation is arguable. Some survey recommended that CI should be performed after diagnosis of PMD as soon as possible and other suggested late approach (14).Young et al. showed that early bilateral simultaneous $\mathrm{CI}$ in children with PMD increases the likelihood of binaural hearing and ensures implantation of the better ear in this population of children whose course is often complicated by formation of scar tissue and ossification within the cochlea (15). Regarding to the results of present study and similar studied we conclude that children with post meningitis deafness could be Benefited from CI. However, Studies with larger sample size and a control group with longer follow-up period for confirming the prognostic factors are recommended.

\begin{tabular}{llllll}
\hline \multicolumn{2}{l}{ Table1. Nerve Response Telemetry (NRT) Findings } & & & \\
\hline No. & $\begin{array}{l}\text { Electrodes inser- } \\
\text { tion }\end{array}$ & $\begin{array}{l}\text { NRT (at the base- } \\
\text { line) }\end{array}$ & $\begin{array}{l}\mathbf{N R T}^{\mathrm{a}} \text { (45 days after } \\
\mathbf{C I})^{\mathrm{a}}\end{array}$ & $\begin{array}{l}\text { NRT (3 months } \\
\text { after CI) }\end{array}$ & $\begin{array}{l}\text { NRT (6 months } \\
\text { after CI) }\end{array}$ \\
\hline $\mathbf{1}$ & Suitable & 0 & 205 & 195 & 194 \\
$\mathbf{2}$ & Suitable & 155 & 145 & 140 & 143 \\
$\mathbf{3}$ & $\begin{array}{l}\text { Drill \& Short elec- } \\
\text { trodes }\end{array}$ & 0 & 201 & 196 & 197 \\
$\mathbf{4}$ & Suitable & 0 & 196 & 194 & 190 \\
$\mathbf{5}$ & Suitable & 195 & 186 & 190 & 193 \\
$\mathbf{6}$ & $\begin{array}{l}\text { Drill \& normal } \\
\text { electrodes }\end{array}$ & 0 & 195 & 196 & 185 \\
\hline $\mathbf{7}$ & Suitable & 205 & 187 & 195 & 185 \\
\hline $\mathbf{8}$ & Suitable & 0 & 195 & 193 & \\
\hline
\end{tabular}

a Abbreviations: $\mathrm{CI}$, cochlear implantation; NRT, nerve response telemetry

\begin{tabular}{|c|c|c|c|c|c|c|}
\hline No. & $\begin{array}{l}\text { CAP }^{\mathrm{a}} \text { (before } \\
\mathrm{CI} \text { ) }\end{array}$ & $\begin{array}{l}\text { CAP ( } 3 \text { months } \\
\left.\text { after } \mathrm{CI}^{\mathrm{a}}\right)\end{array}$ & $\begin{array}{l}\text { CAP ( } 6 \text { months } \\
\text { after CI) }\end{array}$ & SIR $^{\mathrm{a}}$ (before CI) & $\begin{array}{l}\text { SIR (3 months } \\
\text { after CI) }\end{array}$ & $\begin{array}{l}\text { SIR ( } 6 \text { months } \\
\text { after CI) }\end{array}$ \\
\hline $\mathbf{1}$ & 0 & 1 & 2 & 1 & 1 & 2 \\
\hline 2 & 2 & 6 & 6 & 2 & 3 & 4 \\
\hline 3 & 0 & 3 & 3 & 1 & 1 & 2 \\
\hline 4 & 0 & 3 & 4 & 1 & 1 & 2 \\
\hline 5 & 0 & 2 & 3 & 1 & 1 & 1 \\
\hline 6 & 1 & 3 & 4 & 1 & 1 & 2 \\
\hline 7 & 1 & 3 & 4 & 1 & 1 & 2 \\
\hline 8 & 1 & 3 & 4 & 2 & 2 & 3 \\
\hline
\end{tabular}

a Abbreviations: CAP, Categories of Auditory Perception; CI, cochlear implantation; SIR, speech intelligibility rating

\section{Acknowledgements}

The authors acknowledge the parents of children who participated kindly in this survey.

\section{Financial Disclosure}

None declared.

\section{Funding Support}

None declared.

\section{References}

1. Bacciu A, Ormitti F, Pasanisi E, Vincenti V, Zanetti D, Bacciu S. Cochlear implantation in pontine tegmental cap dysplasia. Int Pediatr Otorhinolaryngol. 2010;74(8):962-6. 
2. Bacciu A, Pasanisi E, Vincenti V, Ormitti F, Di Lella F, Guida M, et al. Cochlear implantation in children with cerebral palsy. A preliminary report. Int J Pediatr Otorhinolaryngol. 2009;73(5):717-21.

3. Nikolopoulos TP, Kiprouli K. Cochlear implant surgery in challenging cases. Cochlear Implants Int. 2004;5 Suppl 1:56-63.

4. Rizer FM, Burkey JM. Cochlear implantation in the very young child. Otolaryngol Clin North Am.1999;32(6):1117-25.

5. Durisin M, Arnoldner C, Stover T, Lenarz T, Lesinski-Schiedat A Audiological performance in cochlear implanted patients deafened by meningitis depending on duration of deafness. Eur Arch Otorhinolaryngol.2008;265(4):381-8.

6. Amirsalari S, Ajallouyean M, Saburi A, Haddadi Fard A, Abed M, Ghazavi Y. Cochlear implantation outcomes in children with Waardenburg syndrome. Eur Arch Otorhinolaryngol. 2012;269(10):2179-83.

7. Amirsalari S, Yousefi J, Radfar S, Saburi A, Tavallaie SA, Hosseini MJ, et al. Cochlear implant outcomes in children with motor developmental delay. Int J Pediatr Otorhinolaryngol. 2012;76(1):100-3.

8. Liu X, Yao Y, He G, Zhai L. [Magnetic resonance imaging study and cochlear implantation in post-meningitic deaf patients]. Lin $\mathrm{Ch}$ uang Er Bi Yan Hou Ke Za Zhi. 2004;18(7):399-401.

9. Francis HW, Pulsifer MB, Chinnici J, Nutt R, Venick HS, Yeagle JD, et al. Effects of central nervous system residua on cochlear implant results in children deafened by meningitis. Arch Otolaryngol Head Neck Surg. 2004;130(5):604-11.

10. El-Kashlan HK, Ashbaugh C, Zwolan T, Telian SA. Cochlear implantation in prelingually deaf children with ossified cochleae. Otol Neurotol. 2003;24(4):596-600.

11. Eshraghi AA, Telischi FF, Hodges AV, Odabasi O, Balkany TJ Changes in programming over time in postmeningitis cochlear implant users. Otolaryngol Head Neck Surg. 2004;131(6):885-9.

12. Rotteveel LJ, Snik AF, Vermeulen AM, Mylanus EA. Three-year follow-up of children with postmeningitic deafness and partial cochlear implant insertion. Clin Otolaryngol. 2005;30(3):242-8.

13. Mitchell TE, Psarros C, Pegg P, Rennie M, Gibson WP. Performance after cochlear implantation: a comparison of children deafened by meningitis and congenitally deaf children. J Laryngol Otol. 2000;114(1):33-7.

14. Allegro J, Papsin BC, Harrison RV, Campisi P. Acoustic analysis of voice in cochlear implant recipients with post-meningitic hearing loss. Cochlear Implants Int. 2010;11(2):100-16.

15. Young NM, Tan TQ. Current techniques in management of postmeningitic deafness in children. Arch Otolaryngol Head Neck Surg. 2010;136(10):993-8. 